\title{
DAMPAK DAN FUNGSI MITE SEMAR BAGI KEHIDUPAN MASYARAKAT LERENG GUNUNG ARJUNA
}

\author{
Muhammad Faisal Aristama ${ }^{1}$, Eggy Fajar Andalas ${ }^{2}$, Sugiarti ${ }^{3}$ \\ Pendidikan Bahasa Indonesia, Universitas Muhammadiyah Malang \\ faisalaristama3@gmail.com¹, eggy@umm.ac.id², atika_umm@yahoo.co.id³
}

Artikel diterima: 08 April 2020

Artikel direvisi: 13 Juni 2020

Artikel disetujui: 26 Agustus 2020

\begin{abstract}
Abstrak
Mite Semar hidup di masyarakat lereng Gunung Arjuna. Mite Semar dianggap sebagai cerita suci yang dipercaya kebenarannya oleh masyarakat lereng Gunung Arjuna. Keberadaan mite dalam kehidupan masyarakat kolektif ini memiliki dampak dan fungsi terhadap kehidupan masyarakat. Penelitian ini bertujuan untuk mendeskripsikan dampak dan fungsi mite Semar bagi kehidupan masyarakat lereng Gunung Arjuna. Penelitian ini menggunakan pendekatan etnografi. Penelitian dilakukan selama tiga bulan di dusun Tambakwatu desa Tambaksari Kecamatan Pasuruan Jawa Timur. Pengumpulan data dilakukan dengan teknik observasi, wawancara, dan studi dokumen. Hasil penelitian menunjukkan bahwa mite Semar memiliki dampak terhadap tradisi yang hidup di masyarakat. Hal ini berkaitan dengan integrasi nilai-nilai spiritual dan sosial yang ada pada tokoh Semar ke dalam tradisi yang ada. Selain itu, mite Semar memiliki fungsi sebagai alat pendidikan generasi muda, perekat ikatan sosial, dan alat
\end{abstract}

\begin{abstract}
Semar is a living myth among the community in the Arjuna Mountain. This myth is considered a sacred story believed to be a truth by the community. The existence of myth has an impact and function on people's lives. This study aims to describe the impact and function of myth of Semar on the lives of Arjuna Mountain community. This research uses an ethnographic method. The study was conducted for three months in Tambakwatu sub-village, Tambaksari village, Pasuruan, East Java. Data collection is done by observation, interview and document study techniques. The results showed that the myth has an impact on traditions that live in the community. This is related to the integration of spiritual and social values that exist in the Semar figure into the existing tradition. In addition, the myth has a function as an educational tool for the younger generation, the glue of social ties, and a tool for social control of the community.
\end{abstract}

Keywords: myth of Semar, impact, function, Mount Arjuna

\section{Pendahuluan}

Keberadaan mite menempati posisi penting dalam kehidupan masyarakat kolektif. Hal ini karena mite tidak hanya menjadi cerita penglipur lara, tetapi juga bertalian erat dengan kehidupan sosial maupun spiritual masyarakat pemiliknya (Andalas, 2017; Humaeni, 2018; Sulistyorini \& Andalas, 2017). Mite menjadi autobiografi masyarakat

pemiliknya

karena menggambarkan pandangan dunia masyarakat pemiliknya (Dundes, 1969). Melalui pemahaman terhadap dimensi cerita dapat diperoleh pemahaman terhadap nilai-nilai, gagasan, serta pandangan dunia masyarakat dalam melihat realitas di sekitarnya (Andalas, 2018).

Mite merupakan cerita yang dianggap suci 
Poetika : Jurnal Ilmu Sastra

Vol. 8 No. 1, Juli 2020
DOI 10.22146 /poetika.55300

ISSN 2338-5383 (print) ; 2503-4642 (online) oleh masyarakat pemiliknya (Andalas, 2014; 2015). Karenanya, mite sering menggambarkan dunia yang berbeda dari dunia kita saat ini dengan tokoh-tokoh yang memiliki kekuatan supernatural (Danandjaja, 1997; Hutomo, 1991). Melalui proses adaptasi dengan berpegang pada tata nilai lokal, masyarakat mengendapkan sejumlah tata nilai dan pandangan dunianya agar mite dapat memberikan manfaat dan menjadi pedoman bagi kehidupan masyarakat pemiliknya (Juniarta et al., 2013; Sinapoy 2018; Sufia et al., 2016; Yunus, 2014).

Banyak mite yang hidup di masyarakat Indonesia, salah satunya ialah mite Semar. Mite ini hidup di masyarakat lereng Gunung Arjuna, Jawa Timur. Masyarakat memercayai bahwa Semar merupakan sosok yang melakukan babat alas dan membangun permukiman di wilayah tersebut.

Secara administratif, Gunung Arjuna mencakup tiga wilayah kabupaten, yaitu Kabupaten Malang, Kabupaten Mojokerto, dan Kabupaten Pasuruan. Meskipun begitu, wilayah Utara lereng Gunung Arjuna dikelilingi beberapa desa dan serangkaian situs keramat yang tersebar di sepanjang jalur Utara pendakian ke puncak Gunung Arjuna (Sukmawan, 2014). Wilayah ini mencakup Desa Tambaksari (Kecamatan Purwodadi, Kabupaten Pasuruan), Desa Jatiarjo (Kecamatan Sukorejo, Kabupaten Pasuruan), dan Desa Toyomarto (Kecamatan Singosari, Kabupaten Malang). Ketiga wilayah tersebut memiliki kesamaan aspek sosiokultural antarwilayah karena masih dalam kawasan yang sama.

Keberadaan mite Semar pada masyarakat lereng Gunung Arjuna telah menjadi bagian dalam kehidupan sehari-hari. Bagi masyarakat tersebut, Semar merupakan sosok mitologis yang banyak berjasa bagi kehidupan masyarakat hingga sekarang. Hal ini tercermin dari banyaknya ritus yang muncul sebagai bentuk penghormatan kepada sosok Semar. Berbagai aktivitas masyarakat di wilayah tersebut, khususnya spiritual, selalu memiliki keterkaitan dengan Semar.

Sebagai sebuah produk budaya kolektif masyarakat, mite Semar tidak sekadar dimaknai sebagai cerita semata, tetapi telah menjadi bagian dalam kehidupan kultural masyarakat lereng Gunung Arjuna. Berdasarkan hal tersebut, penelitian ini bertujuan untuk 1) mendeskripsikan dampak mite Semar bagi kehidupan masyarakat lereng Gunung Arjuna dan 2) mendeskripsikan fungsi mite Semar bagi kehidupan masyarakat lereng Gunung Arjuna.

Berdasarkan penelusuran peneliti terdapat beberapa penelitian yang relevan dengan penelitian ini. Pertama, penelitian Wurianto (2009) bertujuan untuk menemukan konsep kearifan lokal dalam kaitannya dengan situs dan mitos yang terkait dengan kelestarian sumber daya alam di Kabupaten Malang. Hasil penelitian menunjukkan cerita lisan, seperti legenda dan mite, selalu menjadi latar belakang bagi keberadaan sumber daya tersebut. Keberadan sumber daya alam ini memiliki makna sakral, potensial, dan sosial bagi masyarakat pemiliknya. Konsepsi "patirtan" dan "panguripan" digunakan sebagai upaya eksploitasi dan pelestariannya.

Kedua, penelitian Andalas (2017) mengenai dampak dan fungsi sosial mite Mbah Bajing bagi kehidupan spiritual masyarakat Dusun Kecopokan Kabupaten Malang. Penelitian ini bertujuan mendeskripsikan dampak dan fungsi mite bagi kehidupan masyarakat. Hasil penelitian menunjukkan mite Mbah Bajing berdampak terhadap cara berpikir, bertindak 
dan berperilaku masyarakat terhadap ruh dan makam Mbah Bajing. Terdapat perlakukan khusus terhadap makam tokoh mitologis ini. Selain hal tersebut, mite bagi masyarakat berfungsi sebagai alat pendidikan, penebal rasa solidaritas, dan pengatur norma kehidupan masyarakat dusun Kecopokan.

Ketiga, penelitian Humaeni (2018) mengenai nilai moral dalam mite masyarakat Banten. Penelitian ini bertujuan untuk memahami bagaimana masyarakat Banten menjalankan dan meyakini mite agama yang menyebar dan dipertahankan antargenerasi hingga saat ini. Hasil penelitian memperlihatkan masyarakat Banten masih melestarikan mite keagamaan karena memainkan peran dan fungsi penting bagi kehidupan masyarakat Banten khususnya generasi muda.

Berdasarkan hal tersebut, penelitian ini penting dilakukan karena sejumlah alasan. Pertama, ketiga penelitian sebelumnya memperlihatkan bahwa pentingnya kedudukan mite bagi masyarakat pemiliknya, baik sosial maupun spiritual. Sebagai sebuah kelompok budaya, keberadaan mite dan posisinya dalam kehidupan masyarakat pastilah berbeda-beda. Karenanya penelitian perlu dilakukan untuk memahami hubungan mite Semar dengan kehidupan masyarakat lereng Gunung Arjuna. Kedua, bagi masyarakat lereng Gunung Arjuna, mite Semar bukan sekadar cerita penglipur lara, tetapi berkaitan erat dengan tradisi dan tata nilai yang hidup di masyarakat. Perlu dilakukan pemahaman terhadap persoalan ini.

Untuk membantu menjelaskan permasalahan penelitian digunakan teori fungsi yang dikemukakan oleh Alan Dundes.
Dalam sudut pandang Dundes (1965), sebagai produk budaya lisan yang dihasilkan oleh suatu masyarakat, produk ini pastilah memiliki fungsi bagi kehidupan masyarakatnya. Sastra lisan, sebagai bagian dari folklor, memiliki fungsi umum, yaitu; 1) alat pendidikan generasi muda; 2) menumbuhkan rasa solidaritas antaranggota masyarakat pemilik kebudayaan; 3) sebagai petunjuk etis masyarakat pemiliknya; 4) alat protes sosial; 5) sarana pelarian dari realitas; dan 6) hiburan. Keenam fungsi ini merupakan fungsi umum yang mengendap dalam produk sastra lisan. Meskipun demikian, tidak semua unsur tersebut selalu ada dalam suatu produk budaya.

Suatu produk budaya memiliki fungsinya masing-masing. Hal ini sesuai dengan keberadaannya dalam kehidupan sosial maupun budaya masyarakat pemiliknya. Dengan melandaskan pada konsepsi ini, mite Semar dipandang sebagai produk sastra lisan yang memiliki fungsi dalam kehidupan masyarakat di lereng Gunung Arjuna. Fungsi ini berkaitan erat dengan kedudukannya dalam kehidupan sosial maupun kultural masyarakat. Sudut pandang Dundes tersebut digunakan sebagai kerangka pemikiran yang melandasi peneliti dalam melihat dampak dan fungsi keberadaan mite Semar dalam kehidupan masyarakat yang ada di lereng Gunung Arjuna.

Penelitian ini menggunakan pendekatan etnografi. Penelitian dilakukan selama tiga bulan, yaitu September-Desember 2019 di Dusun Tambaksari, Dusun Tambakwatu, Kecamatan Purwodadi, Kabupaten Pasuruan, Jawa Timur. Pemilihan lokasi didasarkan kriteria ketersediaan data dan respons masyarakat (Endraswara, 2009). Masyarakat Dusun Tambakwatu masih memercayai mite Semar dan menjalankan tradisi yang berasosiasi dengan 
keberadaan mite Semar. Sumber data penelitian ini adalah; 1) dua orang informan, yaitu pelaku tradisi lisan dan memegang peranan penting dalam pergelaran tradisi dan kehidupan masyarkaat Dusun Tambakwatu, yaitu Bapak Suminto merupakan juru kunci dari situs peninggalan yang ada di Dusun Tambakwatu, dan Bapak Ruman yang merupakan mertua dari Bapak Suminto, 2) catatan observasi selama penelitian, dan 3) dokumen. Data dikumpulkan dengan; 1) wawancara mendalam, 2) observasi partisipan, dan 3) penelusuran dokumen terkait mite dan tradisi Semar.

Teknik analisis data dilakukan dengan display, reduksi, dan kesimpulan. Display mencakup kegiatan 1) mengolah dan mempersiapkan data yang berasal dari transkripsi wawancara, catatan lapangan, dan dokumen. Berbagai data yang telah dikumpulkan diklasifikasikan dan disusun berdasarkan kategorinya sesuai dengan sumbernya, 2) membaca seluruh informasi yang telah didapatkan dan merefleksikan makna secara keseluruhan. Hal tersebut berkaitan dengan gagasan dan informasi umum yang didapatkan selama proses pembacaan data yang telah dikumpulkan. Reduksi data dilakukan dengan 1) menyaring berbagai data yang diperlukan sesuai dengan tujuan penelitian, 2) mengkoding setiap data yang telah didapatkan berdasarkan jenisnya. Dalam proses ini peneliti membagi informasi yang telah didapatkan ke dalam segmen-segmen untuk dimaknai. Secara konkrit hal tersebut dilakukan dengan mengumpulkan data tulisan maupun gambar yang telah dihimpun sebelumnya untuk kemudian mensegmentasikannya ke dalam kategori-kategori dan dilabeli dengan istilah-istilah khusus, 3) setelah dilakukan pengkodingan dilakukan deskripsi setting, orang, kategori-kategori, dan tema- tema sesuai dengan tujuan penelitian, dan 4) menghubungkan setiap tema dan deskripsideskripsi yang telah didapat untuk kemudian dianalisis. Tahap terakhir pengambilan kesimpulan dengan menginterpretasi dan memaknai data.

Secara administratif, dusun Tambakwatu merupakan salah satu dusun yang berada di bawah wilayah administratif Desa Tambasari, Kecamatan Purwodadi, Kabupaten Pasuruan, selain Dusun Gunungsari, Dusun Ampelsari, dan Dusun Krayi. Dusun Tambakwatu secara geografis berada di wilayah paling atas dibandingkan dusun yang lain. Artinya, Dusun Tambakwatu berada pada garis terdalam yang paling dekat dengan situs-situs yang berkaitan dengan tokoh Semar.

Posisi Dusun Tambakwatu yang dekat dengan situs memberikan dampak kuat terhadap kehidupan masyarakat Tambakwatu. Hal ini karena dekatnya akses memberikan pengaruh terhadap intesitas interaksi masyarakat dengan situs yang ada. Kedekatan ini memberikan pengaruh terhadap kuatnya dampak mite bagi kehidupan masyarakat Dusun Tambakwatu.

\section{Dampak Mite Semar pada Kehidupan Masyarakat Lereng Gunung Arjuna}

Keberadaan mite Semar di kalangan masyarakat lereng Gunung Arjuna memberikan dampak terhadap keberadaan tradisi-tradisi masyarakat yang ada di sana. Dampak mite Semar bagi masyarakat lereng Gunung Arjuna dapat diklasifikasikan ke dalam tiga pembagian besar, yaitu: pengaruhnya terhadap tradisi ancak-ancak; petungan Jawi; dan etika hidup masyarakat.

\section{Tradisi Ancak-ancak}

Dalam kehidupan masyarakat Dusun Tambakwatu, Semar dan tokoh pewayangan 
lain diyakini sebagai tokoh yang mendirikan permukiman di wilayah lereng Gunung Arjuna. Semar dipercaya sebagai tokoh yang memiliki kesaktian karena dianggap sebagai manusia setengah dewa.

Semar dalam perjalanannya sebagai pamong atau pemandu Arjuna ditemani oleh satu sosok mitologis lain, yaitu Petruk. Salah satu situs yang diabadikan dan diasosiasikan dengan keberadaan kedua tokoh tersebut adalah Mata Air Ratawu Tampuono. Hingga saat ini, keberadaan situs Mata Air Ratawu Tampuono masih lestari dan menjadi salah satu sumber kehidupan masyarakat Dusun Tambakwatu. Atas jasa Semar yang hingga saat ini masih bisa dirasakan, masyarakat Tambakwatu percaya bahwa segala hal yang terjadi di dusun mereka memiliki keterkaitan dengan ruh Semar. Ruh Semar dipercaya masih berada di sekitar mereka, di berbagai penjuru permukiman masyarakat lereng Gunung Arjuna.

Masyarakat lereng Gunung Arjuna, khususnya Dusun Tambawatu, menghormati segala hal yang berkaitan dengan tokoh Semar. Penghormatan terhadap tokoh mitologis ini diaktualisasikan melalui tradisitradisi yang ada. Menurut Wawancara dengan Pak Ruman (29 November 2019), bentuk penghormatan terhadap arwah leluhur dilakukan melalui tradisi ancakancak (ancakan) pada bulan Suro. Ancakancak atau ancakan merupakan anyaman bambu yang diisi dengan hasil bumi mentah maupun yang sudah diolah menjadi makanan (ayam atau itik) dan dihiasi kertas karton dan balon. Setelah terkumpul, ketua adat atau juru kunci akan membacakan doa-doa.

Upacara pada tradisi ancak-ancak ini selain sebagai bentuk rasa syukur kepada Tuhan atas segala limpahan rezeki yang diberikan, juga sebagai wujud penghormatan dan rasa syukur kepada tokoh Semar yang telah membangun dusun dan menjaga masyarakat setempat dari segala bencana. Pada umumnya, tradisi ancak-ancak juga dapat ditemukan di sejumlah wilayah di Jawa Timur, seperti Situbondo, Bayuwangi, dan lain-lain. Setiap wilayah memiliki tata cara yang berbeda dalam melaksanakannya. Perbedaan ini dapat dilihat berdasarkan pemilihan waktu, tempat, dan prosesi dilakukannya.

Di Dusun Tambakwatu, proses ancakan biasanya dilakukan berbarengan dengan acara bersih desa, yaitu pada bulan Suro. Bulan ini dianggap oleh ketua adat sebagai waktu yang paling tepat bagi penyelenggaraan acara karena merupakan bulan yang baik. Selain sebagai wujud simbolisasi terhadap dibersihkannya segala hal yang buruk dari desa, ritual ini sekaligus menjadi ungkapan rasa syukur atas jasa Semar yang telah melindungi dusun dari berbagai malapetaka.

Pemilihan tempat kegiatan bersih desa juga didasarkan pada beberapa pertimbangan. Ada beberapa kegiatan yang dilakukan di masingmasing rumah warga dan ada juga yang dilakukan secara terpusat di suatu tempat. Kegiatan yang dilakukan secara terpusat ini biasanya dilakukan di tempat yang memiliki nilai sakral atau tempat yang lapang. Pada acara ancakan ini dipercaya bahwa semakin banyak orang yang memperoleh makanan dari ancakan yang telah dibuat maka semakin banyak berkah juga yang ia dapatkan. Karenanya, pada tradisi ini orang yang datang akan berebut untuk dapat memperoleh makanan apapun yang ada di dalam ancak.

Meskipun tujuan utama dari ancakan sebagai wujud rasa syukur kepada Tuhan dan tokoh Semar, tetapi kegiatan ini juga mempererat silaturahmi antarmasyarakat. Hal 
ini dikarenakan emosi atau antusias memengaruhi perasaan religius pelaksaan upacara yang berlangsung. Emosi yang terkandung pada kegiatan tradisi menyebabkan bersatunya unsur sakral dengan unsur alam (Widodo, 1991).

Kegitan tradisi ancakan di Dusun Tambawatu dilakukan berdasarkan pada kemampuan ekonomi masing-masing (wawancara dengan Bapak Ruman, 29 November 2019). Umumnya, bagi masyarakat yang lebih beruntung secara ekonomi akan bersedakah beras, daging, dan lain-lain sedangkan masyarakat yang kurang beruntung diperbolehkan bersedakah jajanjajanan (makanan tradisional). Artinya, kegiatan ini melibatan seluruh masyarakat yang ada. Semua masyarakat ikut turut berpartisipasi untuk memberikan penghormatan dan ungkapan rasa syukur kepada Tuhan dan Mbah Semar. Hal ini selaras dengan yang disampaikan oleh Coleman dan Watson (Endraswara, 2006) bahwa nilai spiritual jauh lebih penting dibandingkan nilai material dalam kegiatan sakral.

\section{Ziarah Petilasan Semar}

Selain tradisi ancakan, keberadaan mite Semar juga memengaruhi kehidupan religius masyarakat Dusun Tambakwatu. Hal ini diaktualisasikan oleh masyarakat Dusun Tambakwatu melalui kegiatan nyekar (ziarah kubur) di petilasan yang dipercaya masyarakat sebagai peninggalan Semar. Nyekar dilakukan pada hari-hari yang dianggap istimewa atau baik. Hari-hari yang dianggap baik untuk melakukan ziarah ke petilasan Mbah Semar, yaitu satu Suro, Kamis Kliwon, dan Jumat Paing.

Penetapan hari baik merupakan salah satu bentuk kepercayaan orang Jawa. Penetapan hari baik dalam kepercayaan Jawa telah ditetapkan dalam bentuk kalender Jawa. Penetapan hari baik atau buruk tidak hanya berkaitan dengan hari libur agama, melainkan dengan petungan Jawi. Menurut Purwadi \& Maziyah (2009), petungan Jawi merupakan perhitungan baik dan buruk yang digambarkan melalui lambang watak suatu hari, tanggal, bulan, tahun, pranata mangsa, wuku, dan lainlain. Melalui unsur-unsur ini dilakukan penetapan keselarasan satu frekuensi dengan frekuensi yang lain (Endraswara, 2010). Artinya, penetapan petungan Jawi mengedepankan nalar dan laku tertentu yang dipercayai oleh masyarakat Jawa. Penetapan terhadap kalender Jawa didasarkan pada peredaran matahari, bulan, bintang, dan faktor eksternal lainnnya.

Berbeda dengan kalender Masehi, hanya terdapat lima hari dalam kalender Jawa. Perhitungan hari menghasilkan pasaran. Pasaran ini terdiri dari Legi, Pon, Paing, Wage, dan Kliwon. Perhitungan hari berdasarkan pasaran ini merupakan manifestasi dari catatan leluhur (Listyana \& Hartono, 2015). Catatancatatan tersebut terhimpun dalam suatu bentuk buku acuan yang disebut dengan primbon. Primbon berisikan mengenai pengalaman suatu kejadian baik maupun buruk yang terjadi pada leluhur. Primbon disampaikan antargenerasi dan menjadi pedoman bagi orang Jawa ketika akan melakukan aktivitas.

Keberadaan primbon sebagai buku acuan utama dalam pelaksanaan kegiatan masyarakat juga terus dilestarikan oleh masyarakat Dusun Tambakwatu. Masyarakat Tambakwatu akan sowan ke situs-situs peninggalan Semar pada malam satu Suro, Kamis Kliwon, dan Jumat Paing. Hal ini merujuk pada hari baik dalam 
sistem kalender Jawa.

Masyarakat sowan ke situs Semar baik secara berkelompok maupun individu. Mereka datang dengan berbagai tujuan. Hal ini dikarenakan adanya kepercayaan bahwa Mbah Semar sejatinya masih mendiami situssitus yang dipercaya sebagai peninggalannya dan senantiasa melindungi warga Tambakwatu. Oleh karena itu, sebelum mengadakan hajatan, tidak sedikit masyarakat Tambakwatu yang akan datang ke situs-situs tersebut untuk memohon restu atas kelancaran kegiatan yang hendak dilakukannya.

Terdapat beragam cara yang dilakukan oleh pengunjung ketika berziarah. Ada pengunjung yang datang dengan membawa sesajian, tetapi tidak sedikit pengunjung yang melakukan ritual ziarahnya secara islami, yaitu dengan membaca ayat-ayat Al-Quran. Pada ketiga hari baik tersebut, satu Suro, Kamis Kliwon, dan Jumat Paing, situs-situs yang dipercaya sebagai peninggalan Semar akan dipadati oleh pengunjung yang tidak hanya berasal dari Tambakwatu, tetapi juga dari berbagai daerah (wawancara dengan Bapak Suminto, 20 November 2019).

Keberadaan mite Semar yang tumbuh subur dan dipertahankan keberadaannya hingga saat ini terbukti telah memberikan dampak terhadap kehidupan religius masyarakat, khususnya yang tinggal di lereng Gunung Arjuna. Sebagai bentuk keyakinan terhadap peristiwa yang ada di dalam cerita, Semar dianggap masih hidup dan menjaga masyarakat lereng Gunung Arjuna dari berbagai bencana. Oleh karena itu, sebagai bentuk rasa syukur dan pengharapan akan berkah dari Semar, masyarakat melakukan kegiatan ziarah ritus di tempat-tempat yang dipercaya sebagai peninggalan Semar.
Melalui aktivitas ini, peziarah berharap dapat memperoleh kebaikan dalam hidupnya setelah pulang dari ziarahnya.

\section{Etika Hidup}

Keberadaan mite Semar dalam kehidupan masyarakat lereng Gunung Arjuna juga berdampak terhadap etika hidup masyarakatnya. Pak Ruman (wawancara 29 November 2019) menyebutkan terdapat beragam motif orang melakukan ziarah ke tempat peninggalan Semar. Ada beberapa yang datang hanya untuk berziarah, sebagian yang lain datang dengan tujuan tertentu seperti ketika akan diselenggarakan pemilihan kepala desa. Orang-orang yang menyalonkan diri sebagai kepala desa harus sowan ke tempattempat yang dianggap keramat dan suci, salah satunya yaitu Arca Semar. Mereka datang sowan ke Arca Semar untuk meminta kelancaran dan kemudahan pada saat menjabat nantinya. Masyarakat percaya jika prosesi nyuwun restu ini tidak dilakukan, maka akan terjadi hal-hal yang tidak diinginkan pada desa Tambaksari.

Keberadaan mite Samar tidak semata-mata berpengaruh pada kehidupan masyarakat Dusun Tambakwatu saja, tetapi tidak jarang masyarakat dari luar Dusun Tambakwatu datang sowan ke Mbah Semar melalui bendabenda peninggalannya. Menurut Pak Ruman (wawancara, 22 November 2019), tidak sedikit orang-orang dari Surabaya, Gresik, hingga Situbondo datang sowan untuk memanjatkan doa tertentu. Masyarakat percaya bahwa jika seseorang bernazar meminta sesuatu di tempat ini akan terkabul.

Jika permohonan peziarah terkabul, biasanya akan dilakukan selamatan sebagai bentuk pensucian petilasan. Akan tetapi, jika janji tersebut tidak dilakukan maka orang 
tersebut akan mendapatkan musibah. Hal ini karena segala bentuk ucapan maupun perilaku manusia disaksikan oleh air, api, tanah, dan angin (wawancara dengan Pak Suminto, 20 November 2019).

Situs peninggalan yang dapat ditemukan di Gunung Arjuna antara lain Goa Antaboga, situs Watu Kursi, situs Batik Dewi Madrim, situs Ratawu atau situs Tampuono, situs Sekutrem, situs Abiyasa, Arca Dwarapala, Sendang Dewi Kunthi, situs Puthuk Lesung, Arca Eyang Semar, dan situs Candi Wesi. Nama benda-benda peninggalan tersebut diambil dari nama tokoh-tokoh yang ada di dalam pewayangan.

Jika ditelusuri lebih mendalam, terdapat keterkaitan antara cerita satu dengan yang lainnya. Berdsarkan hasil wawancara dengan informan, terdapat pengelompokan pembagian kesakralan pada benda-benda peninggalan Semar. Mayarakat lereng Gunung Arjuna percaya bahwa semakin tinggi letak benda peninggalan, maka semakin suci kedudukannya. Situs Eyang Semar berada di ketinggian 1.850 mdpl. Situs penginggal berupa Arca Semar diyakini masyarakat memiliki kekuatan magis. Masyarakat lereng Gunung Arjuna menggunakan situs Eyang Semar untuk ritual yang bersifat sakral. Oleh karena itu, pengunjung awam selalu diingatkan untuk berbicara dan menempatkan diri sebagaimana mestinya.

Masyarakat lereng Gunung Arjuna memercayai hukum sebab-akibat. Segala bentuk perbuatan yang dilakukan akan memiliki pengaruh pada diri sendiri maupun orang lain. Kepercayaan masyarakat dalam kerangka pemikiran ini direalisasikan dalam bentuk wejangan yang diberikan secara turun-temurun pada masyarakat lereng
Gunung Arjuna.

Pak Suminto mengatakan bahwa ketika hendak sowan hal yang harus diperhatikan yaitu tindak-tanduk dalam memperlakukan peninggalan tersebut. Orang-orang yang merendahkan dan berniat merusak peninggalan akan merasakan musibah untuk dirinya (wawancara, 20 November 2019). Mengenai hal ini, Pak Suminto mencontohkan.

"Alah, mek patung, ga ngaruh opo-opo."

("Ah, Cuma patung, tidak memberi pengaruh apapun").

"Eyang opo iki, gak ngewei rezeki opo-opo."

("Kakek apa, tidak akan memberi rezeki (berkah) apapun").

Bentuk perkataan merendahkan tersebutlah yang dianggap sebagai hal tabu bagi juru kunci maupun masyarakat lereng Gunung Arjuna. Bagi siapa pun yang melanggarnya akan mengalami musibah atau akan celaka. Hal ini selaras dengan pandangan Jawa pada umumnya yang melihat bahwa perilaku manusia yang berusaha mengubah tatanan dunia, baik sakral maupun profan, akan menimbulkan ketidakselarasan dengan alam. Manusia Jawa menganggap bahwa masyarakat, alam-lingkungan, dan alam-adikodrati merupakan satu kesatuan yang tidak terpisahkan (Kusbandrijo, 2007).

Secara tidak langsung, dampak mite Semar bagi kehidupan masyarakat lereng Gunung Arjuna, khususnya Dusun Tambakwatu, menekankan pada etika hidup manusia terhadap leluhur. Etika yang terbentuk menghasilkan keserasian antara hubungan manusia dengan manusia, manusia dengan alam, maupun manusia dengan zat adikrodati. Pandangan ini selaras dengan ajaran memayu hayuning bawana yang berarti 'mempercantik dunia yang sudah cantik' melalui perilaku 
kosmis manusia dengan alam-gegayutaning manungsa karo alam (hubungan antara manusia dengan alam). Menjalin hubungan timbal balik secara baik dengan sesama makhluk mencerminkan rasa hormat terhadap Tuhan (gegayutaning manungsa karo Gusti kang Murbeng dumadi ingka akarya jagad) (Pranoto, 2007).

Dampak mite Semar terhadap etika hidup masyarakat lereng Gunung Arjuna terlihat dari pandangan religiusnya. Menurut Andalas (2015) pandangan dunia masyarakat melihat keselarasan antara aspek fisik dan aspek batin. Melalui pencocokan atau menghubung-hubungkan kejadian dengan ruh leluhur merupakan pandangan masyarkaat Jawa yang tercerminkan pada dusun Tambakwatu.

\section{Fungsi Mite Semar pada Kehidupan Masyarakat Lereng Gunung Arjuna}

Keberadaan cerita lisan dalam kehidupan suatu masyarakat memiliki beberapa fungsi. Fungsi ini terkait dengan kebutuhan dan kepentingan anggota masyarakatnya. Keberadaan mite Semar dalam kehidupan masyarakat lereng Gunung Arjuna, khususnya Dusun Tambakwatu, memiliki fungsi sebagai berikut.

Pertama, sebagai alat pendidikan masyarakat. Keberadaan mite Semar dalam kehidupan masyarakat lereng Gunung Arjuna tidak hanya berfungsi sebagai cerita penglipur lara yang diwariskan antargenerasi. Mite Semar dalam kehidupan masyarakat berfungsi sebagai alat pendidikan bagi kehidupan masyarakat. Hal ini seperti yang terlihat pada hari-hari tertentu golongan muda dan golongan tua dari seluruh Desa Tambaksari berkumpul di petilasan Semar. Pada acara ini selain dilakukan doa kepada Mbah Semar, juga menjadi sarana pendidikan bagi generasi muda untuk mengenal kebudayaan leluhurnya. Hal ini sebagai akibat berbagai pengaruh yang datang dari luar memberikan dampak terhadap cara berpikir dan berperilaku generasi muda terhadap kekayaan budayanya. Melalui kegiatan ini, generasi tua mengajak generasi muda untuk ikut terlibat secara aktif dalam kegiatan budaya agar generasi muda lebih peduli dan merasa memiliki terhadap kebudayaannya.

Sistem pengetahuan merupakan hasil dari sejarah perkembangan suatu masyarakat (Ackerman, 2002). Melalui sistem pengetahuan, pola pendidikan dilakukan karena bagi masyarakat Jawa, pembangunan manusia menjadi manusia yang luhur merupakan hakikat dari kehidupan. Hal ini karena sistem pengetahuan masyarakat tradisional Jawa merupakan pertemuan kategori sosial secara vertikal dan kategori sosial secara horizontal. Melalui sistem ini, pewarisan nilai-nilai luhur yang mengendap dalam produk budaya ditransmisikan antargenerasi (Ariani \& Andalas, 2019; Sugiarti \& Andalas, 2018). Pendidikan humaniora bertindak sebagai cultural engineering (Kuntowijaya, 2006). Melalui mekanisme ini, pendidikan terhadap anak-anak dipusatkan pada pembangunan dimensi kemanusiaan. Hal-hal yang bersifat material dipandang hanyalah pelengkap dari kesempurnana perilaku baik bagi manusia Jawa.

Kedua, sebagai alat perekat ikatan sosial. Mite Semar menjadi alat efektif bagi tumbuhnya rasa senasib-sepenanggungan sebagai bagian dari anak keturunan Semar. Masyarakat lereng Gunung Arjuna telah tinggal di wilayah ini secara turun-temurun antargenerasi. Jadi, ikatan sosial yang sudah 
terbangun selama berpuluh-puluh tahun di antara anggota masyarakat telah memunculkan konsepsi mengenai seduluruan di antara mereka. Konsepsi ini tidak memandang hubungan berdasarkan ikatan darah atau garis keturunan, tetapi konsepsi kekeluargaan ini mencakup hal yang lebih luas.

Pada acara-acara tertentu, seperti bersih desa, setiap anggota masyarakat akan ikut terlibat dalam kegiatan. Mulai dari golongan muda hingga golongan tua, semua ikut aktif terlibat dalam kegiatan. Dalam keadaan ini, intensitas waktu untuk berinteraksi dalam bentuk komunikasi maupun gotong-royong akan terbentuk. Masyarakat merasa menjadi anggota komunitas sosial yang sama.

Pada acara sedekah desa, misalnya, masyarakat secara serentak mengadakan selamatan sebagai bentuk ucapan syukur terhadap hasil bumi yang telah diberikan oleh Tuhan dan Mbah Semar. Pada acara ini juga turut diadakan tradisi ancakan. Ancakan dapat diartikan sebagai media untuk mempererat hubungan masyarakat, baik secara spiritual maupun duniawi. Karenanya, melalui hal ini ikatan sosial di antara masyarakat menjadi semakin erat.

Ketiga, mite Semar sebagai alat kontrol sosial bagi masyarakat. Hal ini terealisasikan melalui bentuk penghormatan kepada leluhur. Keberadaan Semar sebagai tokoh mitologis yang dianggap berjasa kepada kehidupan masyarakat lereng Gunung Arjuna hingga saat ini mampu menjadi pengingat bagi setiap pikiran dan tindakan orang-orang di wilayah lereng Gunung Arjuna. Hal ini dapat dilihat dari cara masyarakat memperlakukan benda-benda peninggalan Mbah Semar. Pak Ruman mengatakan, "Sebenere yen menungso ngelakokno keelekan neng tempat leluhur iku mau, leluhur ampun ngapuro, nanging bolo tentorone iku mau sing ora terimo." [sebenarnya jika manusia melakukan suatu kesalahan di tempat bersemayamnya para leluhur, pasti dimaafkan, tetapi pengikut leluhurlah yang tidak terima] (wawancara, 1 Desember 2019).

Salah satu contoh perlakukan yang tidak dibenarkan di tempat yang disakralkan, seperti berbicara kotor, buang air sembarangan, dan lain-lain. Berkaitan dengan ini, Pak Ruman menambahkan, "Alam menungso karo alam alus iku ya podo, kene saling berbarengan. Nanging ya iku mau, alus berarti ora ketok...pesenku Cuma siji, sakdurunge ngelakono opo-opo, pamit disek. Sopo ngerti kene nguyuh kena anak-anak bangsa alus, wong tuane ora terima." [Alam manusia dan alam gaib itu sama, saling beriringan. Tetapi ya itu tadi, gaib bukan berarti tidak ada...Pesan saya Cuma satu, sebelum melakukan apapun, izin terlebih dahulu. Siap tahu ketika buang air seni terkena anak-anak dari bangsa gaib, orang tuanya tidak terima] (wawancara, 1 Desember 2019).

Gambaran tersebut memperlihatkan bahwa keberadaan mite Semar dan berbagai produk budaya yang muncul mengiringi keberadaannya menjadi sebuah alat kontrol sosial bagi masyarakat untuk berlaku hati-hati dalam segala hal. Hal ini tidak hanya berkaitan dengan hubungan manusia dengan zat adikodrati, tetapi juga hubungan antarmanusia. Perhatian terhadap hal tersebut penting karena nilai-nilai luhur yang ada saat ini tidak bisa dipisahkan dari keberadaan budaya di masa lalu (Andalas \& Qur'ani 2017; Hasanuddin, 2015).

\section{Simpulan}

Keberadaan mite Semar dalam kehidupan masyarakat lereng Gunung Arjuna berdampak 
Poetika : Jurnal Ilmu Sastra

Vol. 8 No. 1, Juli 2020
DOI 10.22146 /poetika.55300

ISSN 2338-5383 (print) ; 2503-4642 (online) terhadap kehidupan sakral maupun profan masyarakat, utamanya sakral. Dampak dari keberadaan mite Semar bagi kehidupan masyarakat lereng Gunung Arjuna, yaitu adanya penghormatan terhadap tokoh Semar sebagai tokoh mitologis melalui tradisi ancakan, munculnya ziarah makam Semar, dan memberikan pelajaran etika kehidupan kepada masyarakat lereng Gunung Arjuna. Hal ini memperlihatkan bahwa tokoh "Semar" masih menjadi tokoh mitologis yang merupakan simbol religiositas masyarakat lereng Gunung Arjuna. Semar menjadi tokoh panutan yang memberikan tuntunan bagi kehidupan religius masyarakat lereng Gunung Arjuna. Dengan pelaksanaan tradisi yang diasosiasikan dengan tokoh Semar, masyarakat tidak hanya mengenang, tetapi memperlihatkan pentingnya Semar dalam kehidupan mereka. Hal ini selaras dengan implementasi nilai-nilai yang ada pada diri Semar dalam kehidupan masyarakat lereng Gunung Arjuna. Mite Semar menjadi alat pendidikan masyarakat, perekat ikatan sosial, dan alat kontrol sosial di antara masyarakat lereng Gunung Arjuna.

Penelitian ini tentunya jauh dari kesempurnaan. Penelitian ini hanya menyoroti aspek dampak dan fungsi mite Semar bagi kehidupan masyarakat lereng Gunung Arjuna. Seperti yang telah disampaikan sebelumnya bahwa terdapat banyak situs di wilayah Gunung Arjuna. Situs ini diberikan nama berdasarkan tokoh-tokoh pewayangan yang dipercaya masyarakat sebagai leluhur yang membangun permukiman di wilayah ini. Hal tersebut dapat menjadi penelitian lanjutan dari penelitian ini.

\section{UCAPAN TERIMA KASIH}

Penulis mengucapkan terima kasih kepada Rektor Universitas Muhammadiyah Malang dan Kaprodi Pendidikan Bahasa dan Sastra Indonesia, Fakultas Keguruan dan Ilmu Pendidikan Universitas Muhammadiyah Malang, atas dukungannya terhadap penelitian ini.

\section{DAFTAR PUSTAKA}

Ackerman, R. 2002. The Myth and Ritual School: J. G. Frazer and Cambridge Ritualist. London: Routledge.

Andalas, Eggy Fajar. 2014. "Mitos Mbah Bajing Dalam Sastra Lisan Masyarakat Dusun Kecopokan Kecamatan Sumberpucung Kabupaten Malang." State University of Malang.

Andalas, Eggy Fajar. 2015. "Mitos-Mitos Kabupaten Malang: Cara Orang Jawa Dalam Menjelaskan Dunianya." Puitika 11 (2):150-62.

Andalas, Eggy Fajar. 2017. "Dampak Dan Fungsi Sosial Mitos Mbah Bajing Bagi Kehidupan Spiritual Masyarakat Dusun Kecopokan Kabupaten Malang Jawa Timur." Puitika 13 (1):20-31.

Andalas, Eggy Fajar. 2018. "Cerita Rakyat Dan Tradisi Masyarakat Agraris Nusantara: Mitos Dewi Sri (Jawa) Dan Legenda Putri Mandalika (Sasak)." Pp. 1-12 in KisahKisah Perempuan dan Cerita Rakyat Nusantara2, edited by P. Karyanto. Surabaya: Kajian Sastra dan Budaya Universitas Airlangga.

Andalas, Eggy Fajar, and Hidyah Budi Qur'ani. 2017. Narasi Katulistiwa: Sehimpun Telaah Kritis Atas Kepingan-Kepingan Kisah Manusia Dalam Drama Indonesia. Malang: Kota Tua.

Ariani, M. F., and Eggy Fajar Andalas. 2019. "Kearifan Lokal Malangan Dalam Kumpulan Cerpen Aloer-Aloer Merah Karya Ardi Wina Saputra." Satwika 2 (2):108-18.

Danandjaja, James. 1997. Folklore Indonesia: Ilmu Gosip, Dongeng, Dan Lain-Lain. Jakarta: Pustaka Utama Grafiti.

Dundes, A. 1965. The Study of Folklore. Berkeley: Prentice Hall.

Dundes, A. 1969. "Folklore as a Mirror of Culture." Elementary English 46(4):471- 
82.

Endraswara, Suwardi. 2006. "Mistisisme Dalam Seni Spiritual Bersih Desa Di Kalangan Penghayat Kepercayaan." Jurnal Kejawen 1(2):38-57.

Endraswara, Suwardi. 2009. Metodologi Penelitian Folklor. Yogyakarta: Media Presindo.

Endraswara, Suwardi. 2010. Falsafah Hidup Jawa. Yogyakarta: Cakrawala.

Hasanuddin, W. S. 2015. "Kearifan Lokal Dalam Tradisi Lisan Kepercayaan Rakyat Ungkapan Larangan Tentang Kehamilan, Masa Bayi, Dan Kanak-Kanak Masyarakat Minangkabau Wilayah Adat Luhak Nan Tigo." Kembara 1(2):198204.

Humaeni, Ayatullah. 2018. "Moral Values in Religious Myths of Bantenese Society." Kawalu: Journal of Local Culture 5(1):116.

Hutomo, Suripan Sadi. 1991. Mutiara Yang Terlupakan. Surabaya: HISKI.

Juniarta, H. P., E. Susilo, and M. Primyastanto. 2013. "Kajian Profil Kearifan Lokal Masyarakat Pesisir Pulau Gili Kecamatan Sumberasih Kabupaten Probolinggo Jawa Timur." Ecsofim 28(3):167-78.

Kuntowijaya. 2006. Budaya Dan Masyarakat. Yogyakarta: Tiara Wacana.

Kusbandrijo, Bambang. 2007. Pokok-Pokok Filsafat Jawa dalam Menggali Filsafat dan Budaya Jawa. Jakarta: Prestasi Pustaka Raya.

Listyana, R., and Y. Hartono. 2015. "Persepsi Dan Sikap Masyarakat Terhadap Penanggalan Jawa Dalam Penentuan Waktu Pernikahan (Studi Kasus Desa Jonggrang Kecamatan Barat Kabupaten Magetan Tahun 2013)." Agastya: Jurnal Sejarah Dan Pengajarannya 5(1):11838.

Pranoto, Tjaroko H. P. T. 2007. Spiritualitas Kejawen: Ilmu Kasunyatan, Wawasan,
Dan Pemahaman Penghayatan Dan Pengalaman. Yogyakarta: Kuntul Press.

Purwadi, and Siti Maziyah. 2009. Kitab Primbon Ramalan Jawa. Yogyakarta: Mitra Sejati.

Sinapoy, M. S. 2018. "Kearifan Lokal Masyarakat Adat Suku Moronene Dalam Perlindungan Dan Pengelolahan Lingkungan Hidup." Halu Oleo Law Review 2(2):513-42.

Sufia, R., Sumarmi, and A. Amirudin. 2016. "Kearifan Lokal Dalam Melestarikan Lingkungan Hidup (Studi Kasus Masyarakat Adat Desa Kemiren Kecamatan Glagah Kabupaten Banyuwangi)." Pendidikan 1(4):726-31.

Sugiarti, Sugiarti, and Eggy Fajar Andalas. 2018. "Pespektif Etik Dalam Penelitian Sastra." Malang: UMM Press.

Sukmawan, S. 2014. "Apokaliptisme Sastra Lisan Lereng Arjuna." Sirok Bastra 2 (2):161-71.

Sulistyorini, Dwi, and Eggy Fajar Andalas. 2017. Sastra Lisan: Kajian Teori Dan Penerapannya Dalam Penelitian. Malang: Madani.

Widodo, Sigit Sri. 1991. "Kyai Ageng Gribig Dan Upacara Tradisional Yaqowiyu Di Jatinom Klaten Tahun 1986-1991." Sanata Dharma.

Wurianto, Arif Budi. 2009. "Aspek Budaya Pada Upaya Konservasi Air Dalam Situs Kepurbakalaan Dan Mitologi Masyarakat Malang." Humanity 4(2):80-88.

Yunus, Rasid. 2014. Nilai-Nilai Kearifan Lokal (Local Genius) Sebagai Penguat Karakter Bangsa. Yogyakarta: Deepublish. 